\title{
Perbandingan Respons Dan Produksi Tanaman Karet (Hevea brasilliensis M.) Klon Pb 260 Dan Rric 100 terhadap Aplikasi Stimulan
}

\author{
Comparison of Responses and Productions of Rubber Plant (Hevea brasilliensis M.) \\ PB 260 and RRIC 100 Clones to Stimulan Application \\ Dewi Sartika Andriyani ${ }^{1}$, M. Tahir ${ }^{2}$, Any Kusumastuti ${ }^{2}$ \\ ${ }^{1}$ Program Studi Produksi dan Manajemen Industri Perkebunan, Politeknik Negeri Lampung \\ ${ }^{2}$ Jurusan Budidaya Tanaman Perkebunan, Politeknik Negeri Lampung \\ e-mail: dewsandr@outlook.com
}

\begin{abstract}
ABSTRAK
Penelitian Perbandingan Respons dan Produksi Tanaman Karet Klon PB 260 dan RRIC 100 Terhadap Aplikasi Stimulan ini bertujuan untuk mendapatkan produksi cup lump yang lebih tinggi pada tanaman karet yang diberi perlakuan stimulan dibandingkan dengan tanaman karet yang tidak diberi stimulan. Kadar karet kering yang lebih tinggi pada PB 260 yang telah diberikan stimulan dibandingkan dengan RRIC 100 yang telah diberikan stimulan dan klon yang memberikan respons terbaik terhadap stimulan. Penelitian ini dilakukan di Afdeling 5 PTPN VII Padang Pelawi mulai dari bulan Maret hingga Mei 2019. Metode penelitian ini menggunakan uji-t dengan klon PB 260 dan RRIC 100. Variabel yang diamati adalah lilit batang, sudut sadap, kedalaman sadap, ketebalan sadap, konsumsi kulit, produksi cup lump, dan kadar karet kering. Hasil yang diperoleh dengan menggunakan stimulan meningkatkan produksi cup lump di dua klon yang diteliti, klon RRIC 100 memberikan respons terbaik terhadap stimulan dibandingkan dengan klon PB 260.
\end{abstract}

Kata kunci: Karet, Stimulan, Perbandingan, Produksi, Cup Lump

\section{ABSTRACT}

This study aims to get a higher cup lump production in rubber plants that are given a stimulant treatment compared to rubber plants that are not given a stimulant. Higher levels of dry rubber in PB 260 that has been given a stimulant compared to the RRIC 100 who has been given a stimulant and clone that provide the best responses to the stimulant. This research was conducted at Afdeling 5 PTPN VII Padang Pelawi starting from March to May 2019. The method used a t-test with PB 260 and RRIC 100 clones. The observed variables were stem girth, tapping angle, tapping depth, tapping thickness, skin consumption, cup production lumps, and dry rubber content. The results obtained by the use of stimulants increased cup lump production in two clones studied, RRIC 100 clones gave the best response to stimulants compared with PB 260 clones.

Keywords: Rubber, Stimulants, Comparison, Production, Cup Lump 


\section{PENDAHULUAN}

Luas areal perkebunan karet di Indonesia pada tahun tahun 2016 sebesar 3.639.050 hektar dengan luas perkebunan milik negara sebesar 230.650 hektar, luas perkebunan milik swasta sebesar 316.030 hektar dan perkebunan rakyat sebesar 3.092.370 hektar (Badan Pusat Statistik, 2017). Sesuai data luasan perkebunan karet tersebut, Indonesia menempati urutan pertama sebagai negara yang memiliki perkebunan karet terluas di dunia, namun rendahnya produktivitas tanaman karet di Indonesia serta tidak menunjangnya harga jual karet yang berbanding terbalik dengan tingginya harga pokok produksi karet sehingga masalah ini tidak memberikan dampak positif terhadap perekonomian (Andriyanto \& Darojat, 2016). Produktivitas tanaman karet di Indonesia berada di urutan kedua setelah negara Thailand yang berada diurutan pertama. Luas areal perkebunan rakyat yang lebih besar dibandingkan dengan luas areal perkebunan milik negara dan swasta berakibat pada rendahnya produktivitas tanaman karet di Indonesia..

Untuk menanggulangi masalah rendahnya produktivitas tanaman karet dapat dilakukan dengan menanam klon berproduksi tinggi seperti PB 260 yang juga termasuk klon penghasil lateks cepat (quick starter) (Boerhandy \& Amypalupy, 2010) dan optimalisasi sistem sadap yang salah satunya dengan menggunakan stimulan (Andriyanto \& Darojat, 2016)

Klon PB 260 merupakan klon yang sudah berproduksi tinggi pada tahun sadap awal. Klon PB 260 selama 25 tahun layak diusahakan karena pada tingkat suku bunga 15\%, 13\%, dan 9\% harga diatas USD $1,5 \mathrm{~kg}^{-1}$ dan USD $1,25 \mathrm{~kg}^{-1}$ (Agustina \& Herlinawati, 2017).

Stimulan pada tanaman karet digunakan untuk memacu proses metabolisme karet agar menghasilkan lateks yang optimal serta efisiensi tenaga penyadap. Jenis stimulan yang sering digunakan adalah 2-chloroethyl posponic acid (etephon) yang berfungsi mencegah penggumpalan lateks pada bidang sadap dan memperlama alir lateks dikombinasikan dengan tingkat penyadapan rendah $\mathrm{d} 3$ atau $\mathrm{d} 4$.

Penggunaan stimulan pada tanaman karet memberikan efek yang berbeda pada setiap klon. Sehingga penggunaan stimulan akan efektif pada klon-klon yang mempunyai respons tinggi terhadap aplikasi stimulan seperti klon penghasil lateks lambat (slow starter) (Boerhandy \& Amypalupy, 2010).

Penelitian ini bertujuan untuk mendapatkan produksi cup lump yang lebih tinggi pada tanaman karet yang diberi perlakuan stimulan dibandingkan tanaman karet yang tidak diberi stimulan dan KKK yang lebih tinggi pada tanaman karet klon PB 260 yang telah diberi stimulan dibandingkan dengan tanaman karet klon RRIC 100 yang telah diberi stimulan.

\section{METODE PENELITIAN}

Penelitian dilaksanakan di Afdeling 5 PTPN VII Padang Pelawi. Dimulai dari bulan Maret sampai dengan bulan Mei 2019. Penelitian ini menggunakan metode sampling dengan perlakuan kontrol dan pemberian stimulan pada dua klon tanaman karet berumur 8 tahun yaitu klon RRIC 100 dan PB 260 sebanyak 20 tanaman sampel pada masing-masing klon (10 tanaman sampel kontrol dan 10 tanaman sampel yang diberi stimulan) sehingga terdapat 40 tanaman 
sampel yang diamati. Masing-masing tanaman sampel yang diberikan stimulan ethephon 2,5\% dengan dosis 0,5 gram pohon ${ }^{-1}$ menggunakan sikat.

Analisis data pengaruh pengunaan stimulan menggunakan uji perbandingan dengan bantuan SPSS 16.0 dengan $t$ tabel taraf 5\% dengan rumus sebagai berikut:

$$
t=\frac{\bar{X}_{1}-\bar{X}_{2}}{\sqrt{\frac{\left(n_{1}-1\right) S_{1}^{2}+\left(n_{2}-1\right) S_{2}^{2}}{n_{1}+n_{2}-2}\left(\frac{1}{n_{1}}+\frac{1}{n_{2}}\right)}}
$$

\section{Penentuan Pohon Sampel}

Sampel tanaman karet beberapa klon ditentukan di tengah-tengah kebun dengan hanca sadap yang sama. Lilit batang tanaman sampel minimal $50 \mathrm{~cm}$, Selisih setiap lilit batang sampel $10 \mathrm{~cm}$.

\section{Aplikasi Stimulan}

Aplikasi stimulan dilakukan pada satu hari sebelum pelaksanaan penyadapan. Stimulan diaplikasikan menggunakan sikat gigi di dinding sadap dengan metode GEA (Grove Ethrel Air).

\section{Pelaksanaan penyadapan dan pengadukan}

Pelaksanaan penyadapan dilakukan sesuai waktu yang ditentukan dan saat kondisi cuaca tidak hujan, pengadukan dilakukan setelah 4 jam pelaksanaan penyadapan dengan memberi asam asetat $0,05 \%$ agar tidak kehilangan produksi jika terjadi hujan.

\section{Rumus Perhitungan Kadar Karet Kering}

$$
\mathrm{KKK}=(\mathrm{BK} / \mathrm{BB}) \times 68,5 \%
$$

Keterangan : KKK $=$ Kadar Karet Kering

$$
\begin{aligned}
& \mathrm{BK}=\text { Berat akhir CL } \\
& \mathrm{BB}=\text { Berat awal CL }
\end{aligned}
$$

Produksi karet kering setiap perlakuan dihitung berdasarkan perkalian antara jumlah bobot basah karet kering setiap perlakuan.

\section{HASIL DAN PEMBAHASAN}

Hasil analisis uji perbandingan lilit batang, ketebalan sadap, konsumsi kulit, kedalaman sadap, sudut sadap, produksi CL, dan Kadar karet kering pada klon PB 260 dan RRIC 100 terhadap pemberian stimulan dan tanpa pemberian stimulan dijelaskan pada Tabel 1.

Berdasarkan Tabel 1, tidak terdapat perbedaan antara pemberian stimulan dan tanpa pemberian stimulan pada variabel lilit batang, sudut sadap, ketebalan sadap, kedalaman sadap dan konsumsi kulit. Namun pada variabel produksi cup lump dann kadar karet kering menunjukan perbedaan yang nyata antara pemberian stimulan dan tanpa pemberian stimulan. Nilai varians pada variabel lilit batang memiliki hasil tertinggi yaitu 16,787 dibandingkan 
variabel penunjang lainnya. Hal ini dibuktikan dengan nilai standar deviasi lilit batang yang tinggi yaitu 4,097. Hal tersebut berarti nilai rata-rata pada variabel lilit batang tinggi. Nilai varians yang tinggi berarti fluktuasi data satu dengan data yang lain tinggi atau tidak homogen.

Nilai varians pada variabel kedalaman sadap, ketebalan sadap dan konsumsi kulit rendah berarti data yang diperoleh pada variabel-variabel tersebut cenderung homogen karena pada daerah pengamatan penyadapan dilakukan oleh satu orang penyadap yang sama dan juga dipengaruhi oleh aturan yang ditetapkan oleh perusahaan tempat penelitian.

Tabel 1. Hasil analisis uji perbandingan perlakuan kontrol dan stimulan klon PB 260 terhadap lilit batang, kedalaman sadap, ketebalan sadap, konsumsi kulit, sudut sadap, produksi cup lump, dan KKK

\begin{tabular}{|c|c|c|c|c|c|c|c|c|}
\hline \multirow{2}{*}{ Klon } & \multicolumn{2}{|c|}{ Produksi CL } & \multirow{2}{*}{ Variabel } & \multirow{2}{*}{ Rata-rata } & \multirow{2}{*}{$\sigma$} & \multirow{2}{*}{ sd } & \multirow{2}{*}{ t hitung } & \multirow{2}{*}{$\mathrm{t}$ tabel } \\
\hline & Kontrol & Stimulan & & & & & & \\
\hline \multirow{7}{*}{ PB 260} & \multirow{7}{*}{69,2 gr } & \multirow{7}{*}{$110,4 \mathrm{gr}$} & Lilit batang $(\mathrm{cm})$ & 55,55 & 16,787 & 4,097 & $1,653^{\text {tn }}$ & \multirow{7}{*}{1,833} \\
\hline & & & Ketebalan sadap (mm) & 6,54 & 0,029 & 0,17 & $1,124^{\mathrm{tn}}$ & \\
\hline & & & Kedalaman sadap (mm) & 1,9 & 0,036 & 0,189 & $0,700^{\text {tn }}$ & \\
\hline & & & Konsumsi kulit (mm) & 4,824 & 0,005 & 0,071 & $0,815^{\mathrm{tn}}$ & \\
\hline & & & Sudut sadap & 37,87 & 0,172 & 0,415 & $0,158^{\mathrm{tn}}$ & \\
\hline & & & $\begin{array}{l}\text { Produksi cup lump } \\
\text { (gr/tan) }\end{array}$ & 89,8 & 1,013 & 3,183 & $3,767 *$ & \\
\hline & & & KKK (\%) & 52,139 & 2,229 & 1,493 & $5,842 *$ & \\
\hline
\end{tabular}

Keterangan: * menunjukan nyata, tn menunjukan tidak berbeda nyata

Tabel 2. Hasil analisis uji perbandingan perlakuan kontrol dan stimulan klon RRIC 100 terhadap lilit batang, kedalaman sadap ketebalan sadap, konsumsi kulit, sudut sadap, produksi CL dan KKK

\begin{tabular}{|c|c|c|c|c|c|c|c|c|}
\hline \multirow{2}{*}{ Klon } & \multicolumn{2}{|c|}{ Produksi CL } & \multirow{2}{*}{ Variabel } & \multirow{2}{*}{ Rata-rata } & \multirow{2}{*}{$\sigma$} & \multirow{2}{*}{$\mathrm{Sd}$} & \multirow{2}{*}{ t hitung } & \multirow{2}{*}{$\mathrm{t}$ tabel } \\
\hline & Kontrol & Stimulan & & & & & & \\
\hline \multirow{7}{*}{ RRIC 100} & \multirow{7}{*}{58,34 gr } & \multirow{7}{*}{$123 \mathrm{gr}$} & $\begin{array}{l}\text { Lilit batang } \\
(\mathrm{cm})\end{array}$ & 54,75 & 8,618 & 2,936 & $1,674^{\text {tn }}$ & \multirow{7}{*}{1,833} \\
\hline & & & $\begin{array}{l}\text { Kedalaman } \\
\text { sadap (mm) }\end{array}$ & 6,57 & 0,024 & 0,154 & $0,818^{\text {tn }}$ & \\
\hline & & & $\begin{array}{l}\text { Ketebalan sadap } \\
(\mathrm{mm})\end{array}$ & 1,855 & 0,029 & 0,17 & $0,647^{\text {tn }}$ & \\
\hline & & & $\begin{array}{l}\text { Konsumsi kulit } \\
(\mathrm{mm})\end{array}$ & 1,214 & 0,005 & 0,0713 & $0,010^{\text {tn }}$ & \\
\hline & & & Sudut sadap & 37,87 & 0,266 & 0,516 & $0,084^{\text {tn }}$ & \\
\hline & & & $\begin{array}{l}\text { Produksi cup } \\
\text { lump (gr/tan) }\end{array}$ & 90,67 & $\begin{array}{c}1620,8 \\
5\end{array}$ & 40,259 & $6,169^{*}$ & \\
\hline & & & KKK (\%) & 42,173 & 30,71 & 5,542 & $112,624^{*}$ & \\
\hline
\end{tabular}

Keterangan: *: menunjukan nyata, tn: menunjukan tidak berbeda nyata 
Tabel 3. Hasil analisis uji perbandingan klon PB 260 dan RRIC 100 terhadap lilit batang, kedalaman sadap, ketebalan sadap, konsumsi kulit sudut sadap, produksi CL dan KKK

\begin{tabular}{|c|c|c|c|c|c|c|c|c|}
\hline \multirow[b]{2}{*}{$\begin{array}{c}\text { Perlakua } \\
\text { n }\end{array}$} & \multicolumn{2}{|c|}{ Produksi CL } & \multirow[b]{2}{*}{ Variabel } & \multirow[b]{2}{*}{ Rata-rata } & \multirow[b]{2}{*}{$\sigma$} & \multirow[b]{2}{*}{$\mathrm{Sd}$} & \multirow[b]{2}{*}{$\begin{array}{c}\mathrm{t} \\
\text { hitung }\end{array}$} & \multirow[b]{2}{*}{$\mathrm{t}$ tabel } \\
\hline & $\begin{array}{l}\mathrm{PB} \\
260\end{array}$ & $\begin{array}{c}\text { RRIC } \\
100\end{array}$ & & & & & & \\
\hline \multirow{7}{*}{ Kontrol } & \multirow{7}{*}{$69,2 \mathrm{gr}$} & \multirow{7}{*}{58,34 gr } & Lilit batang $(\mathrm{cm})$ & 53,9 & 12,305 & 3,508 & $0,249^{\mathrm{tn}}$ & \multirow{7}{*}{1,833} \\
\hline & & & Kedalaman sadap (mm) & 6,55 & 0,026 & 0,16 & $1,342^{\mathrm{tn}}$ & \\
\hline & & & Ketebalan sadap (mm) & 1,905 & 0,036 & 0,191 & $0,576^{\mathrm{tn}}$ & \\
\hline & & & Konsumsi kulit (mm) & 1,2145 & 0,002 & 0,048 & $0,043^{\text {tn }}$ & \\
\hline & & & Sudut sadap & 37,05 & 0,296 & 0,545 & $0,158^{\text {tn }}$ & \\
\hline & & & $\begin{array}{l}\text { Produksi cup lump } \\
\text { (gr/tan) }\end{array}$ & 63,77 & 229,942 & 1,516 & $1,681^{\text {tn }}$ & \\
\hline & & & KKK (\%) & 43,868 & 53,091 & 7,286 & $\begin{array}{c}84,715 \\
*\end{array}$ & \\
\hline
\end{tabular}

Keterangan: * menunjukan nyata, tn menunjukan tidak berbeda nyata

Tabel 2 menunjukan bahwa nilai varians pada variabel produksi cup lump lebih tinggi yaitu 1620,85 dibandingkan variabel lainnya, didukung dengan nilai standar deviasi sebesar 40,259. Hal tersebut berarti data pada produksi cup lump menyebar di daerah rerata atau tidak homogen diikuti oleh variabel KKK dengan nilai varians sebesar 30,71 dan nilai standar deviasi sebesar 5,542 kemudian variabel lilit batang dengan nilai varians dan standar deviasi sebesar 8,618 dan 2,936. Variabel-variabel penunjang yang lain menunjukan selisih nilai varians dan rata-rata yang rendah berarti data yang didapat pada variabel-variabel tersebut homogen.

Nilai t hitung pada produksi cup lump dan KKK lebih tinggi dibandingkan nilai t tabel yang menunjukan bahwa perbandingan perlakuan antara kontrol dan stimulan klon RRIC berbeda nyata. Sedangkan t hitung pada variabel penunjang menunjukan nilai t tabel yang lebih rendah dibandingkan dengan thitung yang berarti perbandingan antar perlakuan klon RRIC 100 tidak ada perbedaan yang nyata. Tabel 3 menunjukan perbandingan perlakuan kontrol antara klon PB 260 dan RRIC 100 pada KKK menunjukan berbeda nyata karena t hitung lebih tinggi dari pada $\mathrm{t}$ tabel, namun pada variabel lainnya tidak menujukan adanya perbedaan yang nyata karena nilai t hitung lebih rendah dari pada t tabel. Nilai varians tertinggi terdapat pada variabel produksi cup lump yaitu sebesar 229,942; KKK sebesar 53,091 dan lilit batang sebesar 12,305 yang menunjukan bahwa data pada ketiga variabel tersebut tidak homogen. Nilai varians yang tinggi menunjukan bahwa nilai data tersebar disekitar rerata.

Berdasarkan Tabel 4 perbandingan perlakuan stimulan antara klon PB 260 dan RRIC 100 pada variabel KKK memiliki t hitung yang lebih tinggi dibandingkan dengan t tabel. Hal tersebut berarti perbandingan perlakuan stimulan kedua klon pada variabel KKK berbeda nyata. Sedangakan variabel lain menunjukan nilai thitung yang lebih rendah dibandingkan $t$ tabel, hal tersebut menunjukan bahwa perbandingan perlakuan stimulan antara klon PB 260 dan RRIC 100 tidak berbeda nyata pada variabel yang diuji. Nilai varians tertinggi terdapat pada produksi cup lump sebesar 930,221, lilit batang sebesar 10,147 dan KKK sebesar 9,369 menunjukan bahwa nilai data ketiga variabel tersebut tersebar disekeliling rerata atau tidak homogen.

Variabel penunjang pada setiap tabel menunjukan nilai $\mathrm{t}$ hitung yang lebih rendah dibandingkan $t$ tabel. Artinya, tidak adanya perbedaan yang nyata pada perbandingan klon PB 260 dan RRIC 100 maupun antar perlakuan kedua klon tersebut terhadap variabel-variabel 
penunjang yang diuji. Tidak adanya perbedaan yang nyata pada variabel penunjang yang diuji pada setiap tabel di atas karena kriteria pengambilan sampel pada variabel lilit batang serta adanya peraturan yang berlaku pada tempat penelitian. Seperti pemakain kulit 1,5 mm untuk setiap kali sadap, ketebalan sadap berkisar antara 1-1,5 mm, dan kemiringan sudut sadap $40^{\circ}$.

Produksi cup lump pada setiap tanaman sampel yang diberi aplikasi stimulan lebih tinggi dibandingkan dengan tanaman sampel yang tidak diberikan aplikasi stimulan, hal tersebut terjadi karena adanya gas etilen yang dihasilkan oleh aplikasi stimulan yang dapat menunda pembekuan lateks pada bidang sadap karena dapat menstabilkan tekanan osmotik dan litoid pada tanaman karet (Prasetyo dkk, 2016). Akibat adanya penundaan pembekuan lateks, tanaman yang diberi aplikasi stimulan mengeluarkan lateks dan air yang lebih banyak sehingga produksi lateks pada tanaman sampel yang diberi aplikasi stimulan mengalami peningkatan dibandingkan dengan tanaman sampel yang tidak diberikan stimulan (kontrol).

Tabel 4. Hasil analisis perbandingan klon PB 260 dan klon RRIC 100 perlakuan stimulan terhadap lilit batang, kedalaman sadap, ketebalan sadap, konsumsi kulit, sudut sadap dan KKK

\begin{tabular}{|c|c|c|c|c|c|c|c|c|}
\hline \multirow[b]{2}{*}{ Perlakuan } & \multicolumn{2}{|c|}{ Produksi CL } & \multirow[b]{2}{*}{ Variabel } & \multirow[b]{2}{*}{$\begin{array}{c}\text { Rata- } \\
\text { rata }\end{array}$} & \multirow[b]{2}{*}{$\sigma$} & \multirow[b]{2}{*}{$\mathrm{Sd}$} & \multirow[b]{2}{*}{ t hitung } & \multirow[b]{2}{*}{$\mathrm{t}$ tabel } \\
\hline & PB 260 & $\begin{array}{c}\text { RRIC } \\
100\end{array}$ & & & & & & \\
\hline \multirow{7}{*}{ Stimulan } & \multirow{7}{*}{$110,4 \mathrm{gr}$} & \multirow{7}{*}{$123 \mathrm{gr}$} & Lilit batang $(\mathrm{cm})$ & 56,4 & 10,147 & 3,186 & $0,836^{\text {tn }}$ & \multirow{7}{*}{1,833} \\
\hline & & & Kedalaman sadap (mm) & 6,56 & 0,026 & 0,163 & $0,572^{\text {tn }}$ & \\
\hline & & & Ketebalan sadap (mm) & 1,85 & 0,028 & 0,876 & $0,167^{\text {tn }}$ & \\
\hline & & & Konsumsi kulit (mm) & 1,206 & 0,008 & 0,089 & $0,507^{\text {tn }}$ & \\
\hline & & & Sudut sadap & 37,8 & 0,156 & 0,395 & $0,483^{\text {tn }}$ & \\
\hline & & & $\begin{array}{l}\text { Produksi cup lump } \\
\text { (gr/tan) }\end{array}$ & 116,7 & $\begin{array}{c}930,22 \\
1\end{array}$ & 3,049 & $0,920^{\text {tn }}$ & \\
\hline & & & KKK $(\%)$ & 50,443 & 9,369 & 3,061 & $15,162 *$ & \\
\hline
\end{tabular}

Keterangan: * menunjukan nyata, tn menunjukan tidak berbeda nyata

Kedua klon yang diberi aplikasi stimulan memberikan respons bahwa aplikasi stimulan mempengaruhi produksi CL (Cup lump), nilai rata-rata sampel tanaman yang diberi aplikasi stimulan lebih tinggi dibandingkan dengan tanaman kontrol. Respons terbaik pada aplikasi stimulan terdapat pada klon RRIC 100 hal ini dapat dilihat dari nilai t hitung pada klon RRIC 100 yang lebih tinggi dibandingkan dengan klon PB 260. Peningkatan volume lateks pada klon RRIC 100 terhadap aplikasi stimulan lebih signifikan dibandingkan dengan peningkatan volume lateks pada klon PB 260. Hal tersebut dikarenakan RRIC 100 merupakan klon slow starter atau klon penghasil lateks lambat pada umur awal sedangkan PB 260 merupakan klon quick starter atau klon penghasil lateks cepat pada umur awal.

Klon-klon quick starter (QS) menurut Herlinawati dan Kuswanhadi (2013), yang memiliki fosfat anorganik tinggi dan kandungan sukrosa rendah seperti pada PB 260 hanya perlu adanya pelukaan untuk mengaktifkan metabolisme sel lateks sehingga klon PB 260 kurang responsif terhadap pemberian aplikasi stimulan karena aplikasi stimulan hanya berfungsi sebagai pengurang hambatan pada aliran lateks. Sedangkan klon-klon jenis slow starter lebih responsif terhadap pemberian stimulan untuk mengaktifkan metabolisme sel lateks. 
Penggunaan stimulan pada klon PB 260 sebaiknya diperhatikan karena rentan terkena kering alur sadap yang dapat mempercepat pembukaan sadap atas sehingga menurunkan hasil produksi. Sedangkan untuk klon RRIC 100 yang lebih tahan dengan eksploitasi untuk menanggulangi penyakit kering alur sadap akibat pemberian aplikasi stimulan, sebaiknya dikombinasikan dengan penurunan sistem sadap d3 atau d4. Konsentrasi penggunaan stimulan dan dosisnya juga mempengaruhi terjadinya KAS, sehingga penggunaan stimulan sebaiknya dengan konsentrasi dan dosis anjuran yang ditetapkan.

Aplikasi stimulan tidak mempengaruhi kadar karet kering, aplikasi stimulan hanya berpengaruh pada hasil produksi tanaman karet. Namun kadar karet kering pada kedua klon tanaman sampel yang diberi aplikasi stimulan lebih tinggi dari pada tanaman kontrol, dapat dilihat pada Tabel 1 dan 2 bahwa tanaman sampel yang telah diberi aplikasi stimulan berbeda nyata terhadap tanaman sampel yang tidak diberi aplikasi stimulan (kontrol). Hal tersebut mungkin karena penghitungan kadar karet kering bukan menggunakan skala laboratorium sehingga memungkinkan masih adanya kadar air pada koagulum yang diuji kadar karet keringnya dan penggunaan mangkuk sadap yang baru. Menurut Prasetyo, dkk (2016) kadar karet kering dipengaruhi oleh kebersihan lateks yang dihasilkan dan syarat-syarat penyadapan terpenuhi, seperti kebersihan mangkuk dan adanya kayu bekas irisan sadap.

\section{KESIMPULAN}

Produksi cup lump pada tanaman sampel yang telah diberi stimulan etephon dengan konsentrasi 2,5\% dan dosis 0,5 gr pohon $^{-1}$ lebih tinggi dibandingkan dengan produksi cup lump pada tanaman sampel yang tidak diberi aplikasi stimulan. Kadar karet kering pada klon PB 260 yang telah diberi aplikasi stimulan lebih tinggi dibandingkan dengan klon RRIC 100 yang telah diberi aplikasi stimulan. Klon RRIC 100 memberikan respons yang lebih baik dibandingkan dengan klon PB 260.

\section{DAFTAR PUSTAKA}

Agustina, D.S. \& Herlinawati, E. 2017. Komparasi kelayakan investasi klon karet GT 1 dan PB 260 pada berbagai tingkat harga dan umur ekonomis. Jurnal Penelitian Karet, 35(1): 83-92.

Andriyanto, M. \& Darojat, M.R. 2016. Potensi polyethylene glycol (PEG) sebagai stimulan lateks pada tanaman karet (Hevea brasiliensis Mull. Arg). Agrovigor: Jurnal Agroekoteknologi, 9(1): 73-81.

Boerhandy, I. \& Amypalupy, K. 2010. Optimalisasi produktivitas karet melalui penggunaan bahan tanam, pemeliharaan, sistem eksploitasi, dan peremajaan tanaman. Jurnal Litbang Pertanian, 30(1): 23-30.

Prasetyo, D.E., Hartatie, D. \& Setyoko, U. 2016. Pengaruh stimulansia ethrel 10 PA terhadap produksi lateks tanaman karet (Hevea brasilliensis) pada klon RRIC 100 di perkebunan Kalisanen. Jurnal Ilmiah Inovasi, 16(3): 212-216.

Statistik, B.P. 2017. Statistik Perkebunan Indonesia Komoditas Karet 2015-2017. 